\title{
MACROECONOMIC AND MACRO-FINANCIAL FACTORS OF THE STABILITY OF THE BANKING SECTOR - THE CASE OF THE REPUBLIC OF NORTH MACEDONIA
}

\author{
Blagica Donev \\ Faculty of Economics-Skopje, Ss. Cyril and Methodius University in Skopje \\ tevdovska@gmail.com
}

\begin{abstract}
Banks, as financial institutions, play a vital role in achieving financial stability and economic growth, with their expected contribution through mobilization and allocation of financial resources throughout the economy. Only a reliable and stable banking system that enjoys the trust of economic entities can be an effective intermediary of the resources of the national economy in order to intensify economic development. The role of banks is even more important for developing economies with underdeveloped capital markets. The banking sector is still the primary form of financial intermediation in the Republic of North Macedonia. The study examine the stability of the banking sector in North Macedonia, and explores the macroeconomic, macro financial factors behind stability indicators of banking sector functioning in North Macedonia over the 1996- 2017 period by employing correlations and multiple linear regression model.

Results of the analysis showed that macroeconomic factors are not affecting selected bank stability indicators: NPL and capital adequacy. In addition, macro-financial factors (that include the specific determinants of the banking sector that relate to the size, structure, efficiency of the banking sector, competition) are affecting indicators and can be shown to be reliable early warning indicators.

There is a broad consensus that strong and effective micro- and macroprudential policies are needed to assure a robust and resilient financial system. Author's recommendation is implementation regulatory framework and construction of legal, institutional, regulatory landscape for macro-prudential regulation and policies, that act complementing to microprudential and macroeconomic policies, that have an impact on systemic financial stability.
\end{abstract}

Keywords: Non-performing loans, capital adequacy, macroeconomic factors, macro financial factors, banking sector

JEL classification: JEL G0, JEL G18, JEL G21

\section{INTRODUCTION}

Financial stability is a condition in which the financial system, comprising key financial markets and institutions, is resistant to economic shocks and can perform its core functions smoothly: financial intermediation, risk management and execution of payments. Most definitions of financial stability have in common that it is a state of resilience of stress of financial systems and their ability to function and adapt in times of crisis. The financial system is stable "when it responds solidly to financial imbalances that occur endogenously or because of significant adverse and unforeseen events that may arise from either the real economy or the financial system itself. If it is stable, it will absorb shocks primarily through self-correction mechanisms, preventing side effects from having a disruptive effect on the real economy or the participants in the financial system" (definition by The World bank). Banks, as financial institutions, play a vital role in achieving financial stability and economic growth, with their 
expected contribution through mobilization and allocation of financial resources throughout the economy. The role of banks is even more important for developing economies with underdeveloped capital markets (Zhang, et al., 2013). The banking sector is still the primary form of financial intermediation in the Republic of North Macedonia, representing the largest channel for mobilization of domestic savings and their transformation into a major source of external capital for companies. Financial system regulators understand that a loss of confidence in the banking system can have disastrous consequences for the entire financial system. For this reason, banking stability has always been the ultimate regulatory and supervisory goal of regulators (Brunnermeier, et al., 2009).

Globalization of markets, technological innovations, introduction of new and more complex banking products, complemented by developments in the economic environment, have led to increased risk in the international spread of crises, which has led to the need to minimize contingency risks and increase the strength of international financial system, and thus financial stability to be the subject of interest of national and international institutions.

In an effort to improve the quality and ensure the comparability of the level of financial stability in different countries, The International Monetary Fund (IMF) in 1999 introduced financial soundness indicators. Part of these indicators are compatible with the so-called CAMELS methodology that involves the analysis of indicators that interpret the risks to which banks are exposed: capital adequacy, asset quality, management stability, earnings, liquidity and market risk sensitivity. In parallel, the European Central Bank (ECB) in cooperation with the national central banks and banking supervisors started working on a methodology and collection of socalled macroprudential indicators (MPI) for monitoring the financial soundness of the banking sector with primary motive to identify risky developments in the financial sector, and especially in the banking sector.

The problem that this research deals with is the stability of the banking system of the Republic of North Macedonia. This paper reviews the literature and empirical studies on the determinants and indicators of banking stability. Based on the theoretical background, the sources of vulnerability or potential factors that affect the (in)stability of the banking sector are identified. Furthermore, this paper summarizes the importance of macroeconomic factors and macro-financial factors that may affect the stability of the banking system in the Republic of North Macedonia.

\section{LITERATURE REVIEW}

Financial stability is one of the most widely discussed issues in today's economic literature. The relevance of analyses on financial stability was first recognised during the international financial crises at the end of the 90s, also strengthened by the financial and economic crisis emerging in 2007 and covid-19 pandemic in 2020 . There is also a growing academic literature, much of it covering specific financial stability topics in considerable depth, and some of it providing rigorous anchors for debating determinants of financial stability, as well as policies and instruments implemented for its maintenance. A wide range of instruments is used to assess the stability of the financial system in analytical practice. These include in particular the analysis of quantitative indicators and the combination of different approaches, including the calculation of indicators for financial viability, stress testing and a summary of the development of the financial or banking sector based on a simple aggregate indicator.

Empirical evidence for the determinants of crises and instability in the banking system has a long history. While some studies cover periods of crisis for several binary variable countries and explain the latter with macroeconomic factors using regression models, other studies focus on one country and identify appropriate determinants of country-specific banking system stability. Important studies focus on leading indicators of banking crises. By applying multiple 
regression, and linking a set of explanatory variables to the probability of a binary crisis variable, research shows that low real economic growth, high inflation and high real interest rates significantly affect the likelihood of a banking crisis (Demirgüç-Kunt \& Detragiache, 1998). Banking crises mainly depend on conducting business activities within the banks and may be caused by microeconomic factors. One study pointed out that the balance sheet information is important to calculate the indicators for financial analysis and comparisons between banks to determine the position of banks in the market and the degree of stability (Van den End, 2006). Adverse macroeconomic developments should not cause serious banking problems if the bank's management acts farsightedly and reflects the cyclical nature of the economy in its decisions. Because this is not always the case, and because cyclical fluctuations are sometimes unexpectedly extreme, macroeconomic variables can provide good indicators of the likelihood of increased stress in the banking system (Markus, et al., 2001).Other empirical studies show that banking crises are mainly due to deteriorating economic fundamentals, especially declining asset quality. Furthermore, a banking crisis with significant economic costs often results from the exposure of several institutions to common risks.Third, weaknesses tend to increase over time, reflecting the mutually reinforcing interaction between the financial sector and the real economy. Finally, although the timing of the crisis may be unpredictable, it should be possible to detect the symptoms of increasing financial imbalance. The results of the conducted research show that the use of the indicator credit to GDP, gross investments and asset prices (especially real estate prices) are among the best indicators for forecasting banking crises (Borio \& Lowe, 2002). On the other hand, other study suggest use of quantitative indicators that seek to cover the issue of financial stability as a systemic phenomenon and therefore refer not only to financial institutions and markets, but also to the real and government sector as major debtors of financial institutions, but also the financial infrastructure (Indraratna, 2013).

Other empirical researches create a financial stability index, which includes many economic, financial, and behavioral factors that interact with each other in building the financial system. This is a very difficult task given the complex nature of the financial system and the existence of numerous links between financial market participants, non-financial sectors and financial institutions. Most attempts focus on building a aggregate indicator for the banking sector, which is the most important part of the financial system in terms of financial stability.

Despite considerable practical and intellectual progress in recent years, financial stability analysis is still in its infancy.

Many empirical studies consider macroeconomic and banking specific factors as precursors to bank stability. From the studies that discuss the importance of macroeconomic factors in assessing banking risk (Borio et al. 2014) believe that micro-indicators (bank-specific) and macro-indicators (system-wide) should be used together, and serve as a useful cross-check for each other. While (Drehmann \& Tarashev, 2011) researched a number of macroeconomic, market and banking sector indicators as signals for increasing and releasing the protective layers of capital. The study by (Langrin, 2002) suggests the existence of an early warning system that monitors changes that may occur at the level of macro and microeconomic indicators and works to establish indicators of stability of the banking system. Furthermore, (Kaminsky \& Reinhart, 1999) study the behavior of a number of macroeconomic variables months before and after the crisis in a sample of 20 countries, with the aim of identifying variables that act as "early warning signals" of crises. 


\section{BANKING SECTOR IN THE REPUBLIC OF NORTH MACEDONIA - DEVELOPMENT AND CHARACTERISTICS}

The monetary system of the Republic of North Macedonia was institutionalized in 1992 with the introduction of the "Denar" as the national currency and the adoption of the legal framework. At the time of monetary independence, the banking system was relatively underdeveloped and poor with inherited problems from the previous system.

In order to increase the competitiveness between the banks, more liberal legislation for establishing banks was introduced, which resulted in an increase in the number of banks. However, this later proved to be a mistake, due to the inflow of speculative capital into the banking sector. (Trpeski, 2004). Beneficial to strengthen the confidence of depositors in the financial system in general, especially after the occurrence of episodes of pyramid savings banks, which ended catastrophically, in 1997 the Deposit Insurance Fund was established to protect small depositors. In the following years, significant changes and amendments were made to the legal framework governing the operation of the banking system. Activities have been undertaken to implement the Basel Principles for efficient banking supervision. Up to 2006, improvement of the overall performance of the banking system can be noted, increased competition in the banking market and improvement of operational efficiency and profitability. By strengthening the position of the large banks, the concentration in the banking system remains at a relatively high level. In parallel, there is a trend of increasing market share of banks dominated by foreign shareholders.

The banking sector and the Macedonian economy, as a small and open economy, are inevitably sensitive to developments in the international environment, and the negative effects of the global financial and economic crisis of 2008 have resulted in stagnation of the level of financial intermediation of the banking system. The halved profit of the banks in 2009 is due to the slower activity of the banks and the deteriorating quality of the portfolio.

As of 2017, the banking system in the Republic of North Macedonia consists of banks predominantly owned by shareholders originating from the European Union. In terms of size, several banks are key to the overall banking sector and the domestic economy, and the growth of medium-sized banks is increasingly reducing the importance of the three largest banks in the system. At the end of 2019, in the Republic of North Macedonia, there were 17 deposit taking institutions i.e. fifteen banks and two savings houses. The number of banks owned by foreign shareholders was 11 . The banks in dominantly foreign ownership in 2019 still have the largest share in most of the activities: in lending $80.3 \%$, in total revenues $76.7 \%$ and in total profit $70.8 \%$. By country of origin, highest participation in total capital and reserves has shareholders from Greece $-21,4 \%$, Slovenia- 16,2\%, Turkey-12.2\% and Austria- 11,2\% (NBRNM, 2020).

Although considerably improved over the past several years, North Macedonia's banking system is still relatively underdeveloped compared to Western standards. Banking is very conservative, offering traditional banking services only.The analysis of the National bank of Republic of North Macedonia shows that today the banking sector is healthy, stable and with stronger resistance to shocks, compared to the global economic crisis of ten years ago. The strengthened regulatory and supervisory requirements in the period after the global economic crisis, in line with the strengthened international and European standards, have contributed to this, which lead to further strengthening the protective layers of capital and liquidity of domestic banks, as basic pillars of sector stability.

The charts below show the movement of key indicators of stability of the banking system in the Republic of North Macedonia 


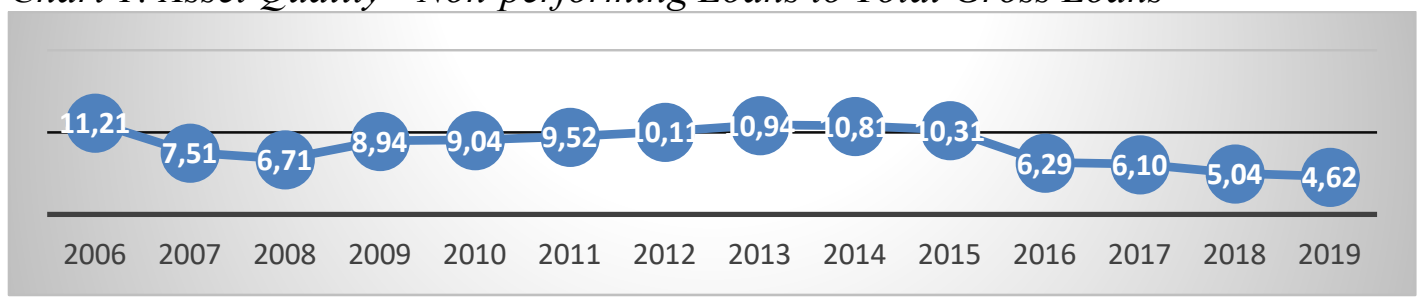

(Source: Financial Soundness Indicators, IMF)

Chart 2: Capital adequacy ratio - Regulatory Capital to Risk-Weighted Assets

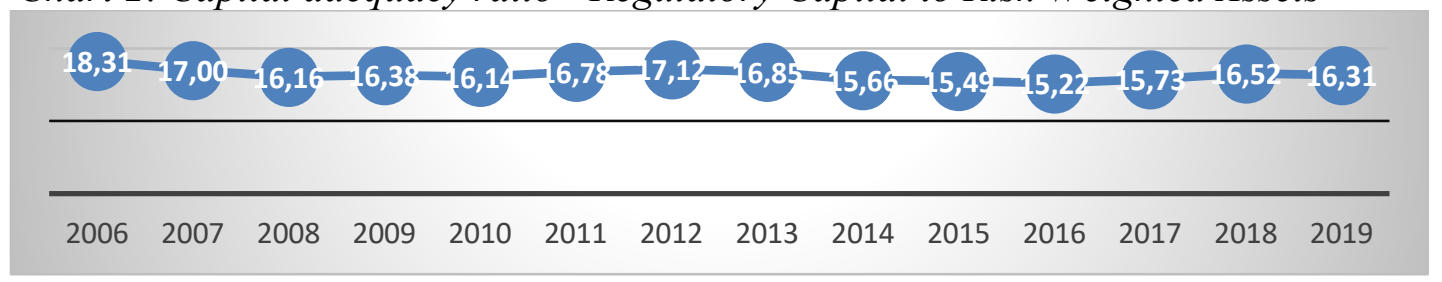

(Source: Financial Soundness Indicators, IMF)

Chart 3: Return on assets - Indicator for profitability

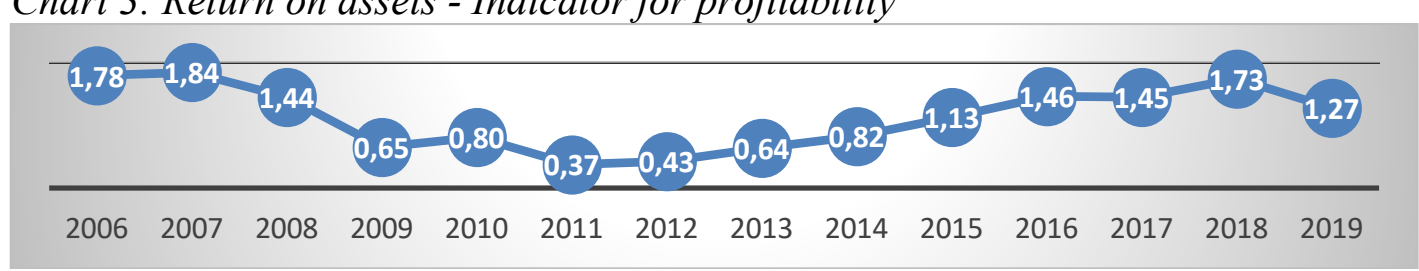

(Source: Financial Soundness Indicators, IMF)

Chart 4: Liquid assets to Total assets (Liquid asset ratio)

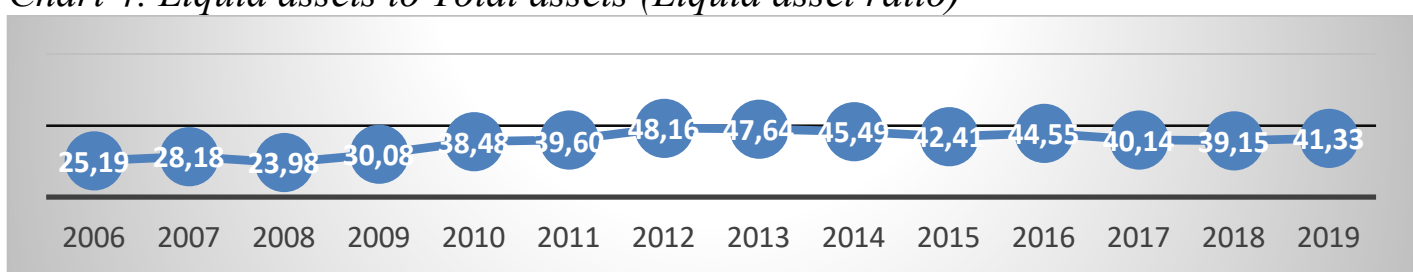

(Source: Financial Soundness Indicators, IMF)

\section{THEORETICAL HYPOTHESES THAT LINK THE STABILITY OF THE BANKING SECTOR WITH THE MACROECONOMIC AND MACRO-FINANCIAL VARIABLES OF THE BANKING SECTOR}

The key indicators for assessing the stability of financial institutions refer to the key areas relevant from the point of view of the banking business and may include groups of indicators of banking soundness: capital adequacy, asset quality, management stability, earnings, liquidity and market risk sensitivity. The capital adequacy indicators measure the banking sector's ability to absorb sudden losses and are thus closest to the "resilience to shocks" concept, whereas the asset quality indicators are directly associated with potential risks to banks' solvency. The profitability indicators measure the ability to absorb losses without any impact on capital, while the liquidity indicators measure banks' resilience to cash flow shocks. Foreign currency exposure is an indicator measuring a bank's risk exposure with regard to movements in asset prices on financial markets. The management quality indicators were ultimately not included in the stability indicators owing to difficulties connected with quantifying indicators that are qualitative in nature (Sundararajan, et al., 2002).

Macroeconomic variables - These variables refer to economic factors at the country level and the degree of their impact on the economic cycle and financial systems, and that light is determined by the flexibility of policies and procedures in the country and the control of fiscal 
and monetary policy, which is reflects the stability of financial banking and is measured by GDP (real growth rates, in\%), unemployment rate (in\%), inflation (end of period, on annual basis, in $\%)$, housing price index - annual rate of change (\%), remittance inflows to GDP (\%).

\section{Table 1: Theoretical hypotheses that link the stability of the banking sector with the} macroeconomic variables of the banking sector

\begin{tabular}{|c|c|}
\hline GDP & $\begin{array}{l}\text { GDP is one of the basic indicators of the size and success of an economy and is a central } \\
\text { macroeconomic category through which the total economic activity of a country is } \\
\text { measured. At the same time, the expectations for economic growth direct expectations to } \\
\text { cause greater projected stability of the banking system and better performance, while, in } \\
\text { case of expected economic downturn, the future stability of the banking system should be } \\
\text { adversely affected. As the economic situation of the business deteriorates during the period } \\
\text { of recession in the economy, the risks from intermediation tend to increase.(Salas \& Saurina, } \\
\text { 2002) found that there is a negative relationship between the real economic growth rate and } \\
\text { NPLs. }\end{array}$ \\
\hline $\begin{array}{l}\text { Price of assets } \\
\text { and real estate }\end{array}$ & $\begin{array}{l}\text { According to economic theory, higher growth in the price of assets and real estate is related } \\
\text { to the boom phase in the business cycle, which may mean an increase in financial } \\
\text { imbalances and has the potential to result in instability of the banking system. For asset } \\
\text { price indicators, it is important to distinguish between real estate and capital prices, as they } \\
\text { reflect different channels of transmission of exogenous shocks to the real economy (Nadya } \\
\& \text { Kick, 2012) }\end{array}$ \\
\hline Inflation & $\begin{array}{l}\text { It is assumed to be positively corelated to non-performing loans (Khemraj \& Pasha, 2009). } \\
\text { Higher inflation would mean higher business costs, which could ultimately result in lower } \\
\text { business returns and lower loan repayment capacity, as well as reduced purchasing power } \\
\text { of people with fixed incomes, which would also reduce their creditworthiness and their loan } \\
\text { repayment capacity. }\end{array}$ \\
\hline $\begin{array}{l}\text { Unemployment } \\
\text { rate }\end{array}$ & $\begin{array}{l}\text { Two main channels for transmitting shocks over banking stability can be identified: the first, } \\
\text { trough the effect of non-performing loans - an increase in the unemployment rate will cause } \\
\text { a reduction in the repayment capacity of households, causing an increase in the default rate; } \\
\text { and the second through the demand for new loans - the increase in the unemployment rate } \\
\text { can result in a significant reduction in the demand for new loans, which can lead to a } \\
\text { significant deterioration of the relationship between interest-bearing assets and deposit } \\
\text { interest liabilities. }\end{array}$ \\
\hline Remittances & $\begin{array}{l}\text { The literature suggests that remittances have a stronger impact on growth in less developed } \\
\text { financial economies. This indicator also indicates the extent to which the country's financial } \\
\text { system is linked to international financial markets. They are an alternative source of funding } \\
\text { for investments that help solve liquidity problems. Monetary transactions as a result of } \\
\text { remittances have a significant impact on financial institutions, especially the banking sector } \\
\text { in the host economy. Remittances have a positive impact on the development of credit } \\
\text { markets along with the expansion and deepening of finance (Orozco, 2006). Therefore, this } \\
\text { results in increased demand for financial products and services, which in turn leads to } \\
\text { institutional development. In addition, banks and other financial institutions are more } \\
\text { willing to lend to families that receive remittances as they are seen as a stable source of } \\
\text { income (Čihák, et al., 2013). In addition, remittances increase lending capacity to other } \\
\text { members of the community (Aggarwal, et al., 2011). Thus, remittances directly affect the } \\
\text { recipient family, but also indirectly serve the financial institution and the community. }\end{array}$ \\
\hline
\end{tabular}

(Source: Authors own elaboration)

Macro-financial variables of the banking sector - include the specific determinants of the banking sector that relate to the size, structure, efficiency of the banking sector over time. These determinants include indicators such as private sector loans granted by banks and savings houses (lending to private sector), weighted interest rates on total denar loans, concentration of the banking sector, Lerner index - a measure of monopoly, bank deposits in of GDP, share of foreign banks among total banks and profitability indicators of the banking sector. 


\begin{tabular}{|c|c|}
\hline $\begin{array}{l}\text { Profitability } \\
\text { (efficiency) of } \\
\text { the banking } \\
\text { sector - ROA } \\
\text { and ROE }\end{array}$ & $\begin{array}{l}\text { Efficiency indicators can also provide signals for the health of the financial industry. Many } \\
\text { studies have shown that strong capital levels are associated with efficient banking } \\
\text { performance, as well-performing banks are able to generate higher profits, which enhances } \\
\text { their solvency; on the other hand, the level of non-performing loans may be negatively } \\
\text { related to the efficiency of banks (Berger \& Humphrey, 1997) (Berger \& Mester, 1997). }\end{array}$ \\
\hline $\begin{array}{l}\text { The } \\
\text { concentration in } \\
\text { the banking } \\
\text { sector }\end{array}$ & $\begin{array}{l}\text { There are opposing views -First, larger banks can create greater protective layers of capital } \\
\text { and profits, making them less sensitive to macroeconomic and liquidity shocks. Second, } \\
\text { supervisory bodies over larger banks focus on effective supervision in order to mitigate } \\
\text { the risk of contagion across the system of concentrated financial markets. Third, larger } \\
\text { banks provide better monitoring on lending. Fourth, larger banks are effectively } \\
\text { diversifying their loan portfolios and related risk as they enjoy better economies of scale. } \\
\text { According to the other hypothesis, the stability of larger banks is declining in a } \\
\text { concentrated market and raises the question of the moral hazard due to the fact that those } \\
\text { banks that are larger may be considered "too large to fail" and are expected to to receive } \\
\text { state guarantees (Ali \& Puah, 2018). }\end{array}$ \\
\hline $\begin{array}{l}\text { The competition } \\
\text { in the banking } \\
\text { sector }\end{array}$ & $\begin{array}{l}\text { Increased competition in the banking sector may affect the health of the financial system. } \\
\text { In a situation where many banks are competing, profit margins are eroded and banks can } \\
\text { take excessive risks to increase yields while deteriorating the quality of the loan portfolio } \\
\text { and thus increase the bank's vulnerability (Berger, et al., 2017). On the other hand, another } \\
\text { study found a negative relationship between lending market power and portfolio risk and } \\
\text { showed that non-performing loans decrease with increasing lending market power, which } \\
\text { promotes financial stability (Jimenez, et al., 2007). }\end{array}$ \\
\hline $\begin{array}{l}\text { The share of } \\
\text { foreign } \\
\text { ownership in } \\
\text { domestic banks }\end{array}$ & $\begin{array}{l}\text { Foreign ownership is expected to bring advanced technology, modern banking techniques } \\
\text { and superior management skills. On the one hand, greater presence of foreign banks can } \\
\text { lead to greater banking efficiency and competition in domestic financial systems. } \\
\text { However, the individual characteristics of the domestic banking system affect the } \\
\text { performance of foreign banks (Claessens \& Forbes, 2001). On the other hand, foreign } \\
\text { banks can provide a channel for cross-border contagion when as they can easily transmit } \\
\text { foreign shocks from one region to another. }\end{array}$ \\
\hline Lerner index & $\begin{array}{l}\text { A measure of market power in the banking market and is a frequently applied measure of } \\
\text { competitiveness in the banking system that has a long list of obvious benefits: greater } \\
\text { efficiency in the production of financial services, higher quality financial products and } \\
\text { more innovation. When financial systems become more open and contestable, generally } \\
\text { this results in greater product differentiation, a lowering of the cost of financial } \\
\text { intermediation and more access to financial services. However, when we turn to the issue } \\
\text { of financial stability, it is no longer so obvious whether competition is beneficial or not, } \\
\text { with a continuing debate among academics and policymakers alike (Anginer, et al., 2013). }\end{array}$ \\
\hline
\end{tabular}

(Source: Authors own elaboration)

\section{METHODOLOGY}

The basic research techniques that was conducted for this research is the use of correlation analysis and multiple linear regression model in the observed banking system of the Republic of Northern Macedonia.

The data for the variables in the research was gathered using a secondary source from the World Bank database -Global Financial Development Database (https://www.worldbank.org/en/publication/gfdr/data/global-financial-developmentdatabase), for that purpose, the version of the database October 2019 was used. The data on macroeconomic variables are taken from the National Bank of the Republic of North Macedonia - Basic economic indicators and real estate prices (https://www.nbrm.mk/osnovni_ekonomski_pokazateli.nspx). The data for some of the indicators for monitoring the stability of the banking system are taken from the IMF database Financial Soundenss indicators (https://data.imf.org/?sk=51B096FA-2CD2-40C2-8D090699CC1764DA\&sId=1411569045760). The analysis includes annual observations for the 
Republic of North Macedonia for the period from 1996 to 2017. The construction and evaluation of the models is done in the statistical software package SPSS.

\subsection{Correlation}

In order to determine whether there is a quantitative dependence (correlation) between the variations of the observed phenomena and if there is to what degree or intensity, a correlation was made between all pairs of variables - macroeconomic factors, macro-financial factors and banking stability indicators. The most familiar measure of dependence between two quantities (variables) is the Pearson product-moment correlation coefficient or "Pearson's correlation coefficient", commonly called simply "the correlation coefficient". Mathematically, it is defined as the quality of least squares fitting to the original data. It is obtained by taking the ratio of the covariance of the two variables in question of our numerical dataset, normalized to the square root of their variances.

The Pearson's correlation coefficient, or bivariate correlation, is a measure of the linear correlation between two variables $\mathrm{A}$ and $\mathrm{B}$.

$\rho_{A B}=\frac{C O V_{A B}}{\sigma_{A} \sigma_{B}}$

The correlation coefficient $\rho_{A B}$ ranges from - 1 to 1 . A value of 1 implies that a linear equation that perfectly describes the relationship between $\mathrm{A}$ and $\mathrm{B}$ where all data points lying on line $\mathrm{A}$ increases as $\mathrm{B}$ increases. A value of -1 means that all data points lie on a line for which $\mathrm{A}$ decreases with increasing $\mathrm{B}$. A value of 0 implies that there is no linear correlation between the variables.

Table 3 summarize the interpretation of variables related to the stability of the banking system in which the estimated correlation coefficients are statistically significant at the level of $99 \%$ :

Table 3: Summary of correlation made between all pairs of variables - macroeconomic factors, macro-financial factors and banking stability indicators.

\begin{tabular}{|c|c|c|}
\hline & Positive correlation & Inverse correlation \\
\hline Z- score is: & $\begin{array}{l}\text { in strong positive correlation with the weighted interest } \\
\text { rates on total loans denominated in MKD }(.840) \text {, } \\
\text { indicator on the concentration of the banking sector } \\
(.850) \text {, while in moderately positive correlation with the } \\
\text { Lerner index (.617) and the liquidity indicator }(.575) \text {. }\end{array}$ & $\begin{array}{l}\text { in strong inverse e correlation } \\
\text { with remittances in relation to } \\
\text { GDP (-.677), bank deposits in } \\
\text { relation to GDP (-.896) and the } \\
\text { share of foreign banks }(-.890)\end{array}$ \\
\hline $\begin{array}{l}\text { The indicator for } \\
\text { non-performing } \\
\text { loans is: }\end{array}$ & $\begin{array}{l}\text { in strong positive correlation with weighted interest } \\
\text { rates on total loans in MKD }(.920) \text {, weighted interest } \\
\text { rates on total deposits in MKD }(.831) \text { and indicator the } \\
\text { concentration of the banking sector }(0.720) \text {. }\end{array}$ & $\begin{array}{l}\text { in strong inverse correlation with } \\
\text { Bank deposits relative to GDP (- } \\
.899) \text {, share of foreign banks (- } \\
.931) \text {, non-performing loan } \\
\text { provisions (-.834) and moderate } \\
\text { inverse correlation with foreign } \\
\text { currency remittances relative to } \\
\text { GDP (-699) }\end{array}$ \\
\hline $\begin{array}{l}\text { The indicator of } \\
\text { the banking } \\
\text { capital in } \\
\text { relation to the } \\
\text { total assets is: }\end{array}$ & $\begin{array}{l}\text { in strong positive correlation with weighted interest } \\
\text { rates on total loans denominated in MKD }(.725) \text {, } \\
\text { indicator on the concentration of the banking sector } \\
(.765) \text {. } \\
\text { The indicator in strong positive correlation with other } \\
\text { indicators of banking stability: capital adequacy }(.980) \text {, } \\
\text { liquidity }(.883)\end{array}$ & $\begin{array}{l}\text { in strong inverse correlation with } \\
\text { bank deposits in relation to GDP } \\
(-.912) \text {, the share of foreign } \\
\text { banks (-.939), as well as the } \\
\text { loans indicator in relation to } \\
\text { bank deposits }(-.860)\end{array}$ \\
\hline $\begin{array}{l}\text { The indicator of } \\
\text { loans in relation } \\
\text { to bank deposits } \\
(\%) \text { is: }\end{array}$ & $\begin{array}{l}\text { in moderately positive correlation with the following } \\
\text { indicators: weighted interest rates on total loans } \\
\text { denominated in MKD }(.663) \text {, the concentration of the } \\
\text { banking sector }(.613) \text {, Lerner index }(.668)\end{array}$ & $\begin{array}{l}\text { in moderately inverse correlation } \\
\text { with bank deposits in relation to } \\
\text { GDP (-.625), share of foreign } \\
\text { banks (-.939), foreign currency }\end{array}$ \\
\hline
\end{tabular}




\begin{tabular}{|c|c|c|}
\hline & & $\begin{array}{l}\text { remittances in relation to GDP (- } \\
.695) \text {. This indicator is strongly } \\
\text { inverse correlated with the } \\
\text { following indicators of stability: } \\
\text { bank capital in relation to total } \\
\text { assets (-.860), as well as } \\
\text { provisions for non-performing } \\
\text { loans (-.935) }\end{array}$ \\
\hline $\begin{array}{l}\text { The capital } \\
\text { adequacy ratio } \\
\text { is: }\end{array}$ & $\begin{array}{l}\text { in strong positive correlation with weighted interest } \\
\text { rates on total loans denominated in MKD }(.937) \text {, the } \\
\text { concentration of the banking sector }(.824) \text {. This } \\
\text { indicator is strongly correlated with the following } \\
\text { indicators of stability: bank capital in relation to total } \\
\text { assets }(.980) \text {, liquidity indicator - Short-term assets in } \\
\text { relation to deposits and short-term financing }(.890)\end{array}$ & $\begin{array}{l}\text { in moderately inverse correlation } \\
\text { provisions for non-performing } \\
\text { loans (-.685), and in strong } \\
\text { negative correlation with bank } \\
\text { deposits in relation to GDP (- } \\
.933)\end{array}$ \\
\hline $\begin{array}{l}\text { Liquidity } \\
\text { indicator } \\
\text { Short-term } \\
\text { assets in relation } \\
\text { to deposits and } \\
\text { short-term } \\
\text { financing }(\%) \text { is: }\end{array}$ & $\begin{array}{l}\text { in strong positive correlation with the following } \\
\text { indicators of financial stability: bank capital in relation } \\
\text { to total assets }(0.883) \text { and capital adequacy }(.890) \text {, while } \\
\text { in moderately positive correlation with the following } \\
\text { indicators: with weighted interest rates on total loans } \\
\text { denominated in MKD (.707), the concentration of the } \\
\text { banking sector }(.681) \text {. }\end{array}$ & $\begin{array}{l}\text { in moderately inverse correlation } \\
\text { with Bank deposits relative to } \\
\text { GDP (-.760), Share of foreign } \\
\text { banks }(-.671)\end{array}$ \\
\hline $\begin{array}{l}\text { The indicator } \\
\text { net foreign } \\
\text { exchange } \\
\text { position in } \\
\text { relation to } \\
\text { capital (market } \\
\text { risk sensitivity) } \\
\text { is: }\end{array}$ & $\begin{array}{l}\text { in strong positive correlation with the unemployment } \\
\text { rate }(.791) \text {, lending to the private sector }(.813) \text {, the } \\
\text { following indicators of financial stability of bank capital } \\
\text { in relation to total assets }(0.780) \text { and the liquidity } \\
\text { indicator }(.729) \text {, while in moderate positive correlation } \\
\text { with the concentration of the banking sector }(.688) \text {. }\end{array}$ & $\begin{array}{l}\text { in strong negative correlation } \\
\text { with Bank deposits in relation to } \\
\text { GDP (-.938), The share of } \\
\text { foreign banks }(-.807)\end{array}$ \\
\hline $\begin{array}{l}\text { Profitability } \\
\text { indicators }\end{array}$ & $\begin{array}{l}\text { moderately positively correlated with the private sector } \\
\text { lending indicator }(.537)\end{array}$ & \\
\hline
\end{tabular}

(Source: Authors own elaboration)

\subsection{Basics of multiple linear regression model}

In order to determine the effect of macroeconomic and macro-financial factors on the stability of the monitored banking system of the Republic of North Macedonia, a multiple linear regression model was applied. The multiple linear regression model defines the dependence between the dependent (endogenous) variable $\mathrm{Y}$ and a group of independent (exogenous) variables: $\mathrm{x} 1, \mathrm{x} 2, \mathrm{x} 3, \ldots, \mathrm{x \kappa}$. However, in order to examine the nature of the relationship between the phenomena, the variables (factors) are identified, and then a sample of size $n$ is drawn for selected values of the independent variables of the base population.

The multiple linear regression equation is as follows: $Y_{i} \equiv \beta_{0}+\beta_{1} x_{1}+\beta_{2} x_{2}+\ldots+\beta_{k} x_{k}+\varepsilon_{i}$ where $y_{i}$ го is the appropriate indicator of stability $i$ (the analysis includes a total of 2 indicators of stability - non-performing loans and capital adequacy), $\mathrm{k}$ is the number of independent variables and $x_{i}^{\prime}$ is the explanatory variable, $\beta_{0}, \beta_{1}, \beta_{2}, \ldots \beta_{k}$ are the parameters of the model. The model's random error (residual) term is marked with $\varepsilon_{i}$.

The observation period is from 1996 to 2017 and covers 22 observations. The explanatory variables used in the analysis are divided into a group of macroeconomic variables and a group of macro-financial variables of the banking system. Regression is constructed for each group of explanatory variables separately. Furthermore, in order to determine the linear dependence between the independent variables, on the one hand, as well as the individual dependent 
variables, on the other hand, a calculation of the correlation analysis is given, through the socalled correlation coefficient.

From the obtained results (presented in Annex 1) it can be concluded that the macroeconomic variables do not have a significant impact on the indicator NPLs. Impact of the variable NPLs has only a part of the variables from macro-financial variables of the banking system at the level of significance $1 \%$, the other explanatory variables are insignificant.

The coefficient before the indicator weighted interest rates on total deposits in MKD shows that its increase by 1 percentage point leads ceteris paribus to increase the dependent variable NPLs by 0.339 percentage points. Ratios before the indicator concentration in the banking sector, banks' deposits relative to GDP (\%), ROE shows that its increase by 1 percentage point leads ceteris paribus to decrease the dependent variable NPLs by $-.827,-1.328$ and -215 percentage points respectively. From the obtained results, it can be concluded that the macroeconomic variables do not have a significant impact on the capital adequacy ratio.

The coefficient before the banks' deposit ratio in relation to GDP (\%) shows that its increase by 1 percentage point leads ceteris paribus to decrease the dependent variable capital adequacy by $-1,068$ percentage points respectively, at a level of significance of $1 \%$. While at the significance level of 5\%, the coefficient before the Lerner index shows that its increase by 1 percentage point leads ceteris paribus to decrease the dependent variable capital adequacy by .277 percentage points respectively.

\section{CONCLUSION}

The banking system is still the primary form of financial intermediation in the Republic of North Macedonia, representing the largest channel for mobilization of domestic savings and their transformation into the main source of external capital for companies. In the development period after its independence, it has made significant progress and growth. Activities have been undertaken for the implementation of the Basel principles for efficient banking supervision, and in accordance with international and European standards, the legal framework governing the operation of the banking system has been established.

The financial stability indicators show that the quality of banks' assets has improved through the indicator of non-performing loans to total gross loans, noting a downward trend of $11.21 \%$ in 2006 to $4.62 \%$ in 2019 . The capital adequacy ratio is stable and its average is $16.40 \%$. The capital adequacy ratio of the banking system is higher by 1.1 percentage point of the total regulatory and supervisory requirements, including the activated capital buffers determined as of 31.12.2019. Indicator ROA in observed period showed that the banking sector is at the level of average efficiency. Except, the global financial crisis in 2009 affected the profitability of Macedonian banks resulting in negative ROA indicators for the crisis and post-crisis period. In terms of liquidity, the banking system is liquid and maintains stable liquidity, at the level of $41.33 \%$ in the last year.

The research showed that the macroeconomic variables do not have a significant impact on the NPLs. This variable is important because it indicates the quality of assets in the banking sector. Impact on the variable the NPLs has only a part of the variables of macro financial factors of the banking system, the other variables are not statistically significant.That is, the increase in interest rates leads to an increase in NPLs, while the increase in the concentration in the banking sector, banks' deposits to GDP (\%), as well as profitability expressed through ROE affect the reduction of the NPLs. The obtained results confirm the assumptions that the larger banks provide better lending monitoring, which results in a better loan portfolio and a smaller amount of NPLs. As well as confirmation of the assumption about the negative relationship between the level of NPLs and the efficiency of banks. Any bad credit in the financial sector increases the possibility of a leadership crisis and results in unprofitability. 
The research showed that the NPLs indicator is in a strong positive correlation with the indicators for weighted interest rates on deposits (loans) and a strong negative correlation with the participation of foreign banks, non-performing loan provisions. The participation of foreign banks is expected to bring advanced technology, modern banking techniques and superior management skills and thus lead to greater banking efficiency and competition in domestic financial systems.

Furthermore, from the obtained results it can be concluded that macroeconomic variables do not have a significant impact on the capital adequacy ratio as well. This indicator is important because it determines the capacity of the bank to meet obligations and other risks, as well as to amortize the shocks of crises. From the obtained results, it was determined that the increase of the banks' deposits ratio in relation to GDP (\%) and the Lerner index leads to a decrease in the capital adequacy ratio. It can be concluded that increase of the size and market power in the banking market disrupts capital adequacy, ie confirms the hypothesis that the stability of larger banks decreases in a concentrated market and raises the question of moral hazard due to the fact that those banks that are larger may be considered "too large to fail" and are expected to receive government guarantees.

The research showed that capital adequacy is strongly correlated with interest rates, the concentration of the banking sector. This indicator is strongly correlated with the following indicators of stability: bank capital in relation to total assets, the liquidity indicator, which is logical. While in a strong negative correlation with bank deposits in relation to GDP - the indicator of deposit resources available to the banking sector for its lending activities.

It is obvious that the indicators that refer directly to the soundness of the banking system are ideal for predicting banking crises, and hence the recommendation would be early monitoring and maintenance of appropriate levels of capital adequacy, asset quality, stable management, profitability, liquidity and market risk sensitivity in order to maintain stability. There is no doubt that the performance of banks and the likelihood of disruption of the banking system are mainly driven by business activities and developments within the banking sector. Unfavorable macroeconomic developments should not cause serious banking problems if the bank's management is satisfactory. Qualitative components such as supervision, implementation of the legal framework and international standards such as proper regulation of accounting and internal audit certainly remain important. Existing changes in the international financial markets, the development of new banking products, services and instruments impose a constant revision of the rules and principles of operation of banks on the one hand, as well as the need to strengthen prudent banking supervision on the other hand. There is a broad consensus that strong and effective micro- and macroprudential policies are needed to assure a robust and resilient financial system. Author's recommendation is implementation regulatory framework and construction of legal, institutional, and regulatory landscape for macro-prudential regulation and policies that act complementing to microprudential and macroeconomic policies that have an impact on systemic financial stability in order to identify and reduce the risks to financial stability that occur in both temporal and structural dimensions.

\section{REFERENCES}

1. Aggarwal, R., Demirgüç-Kunt, A. and Pería, M.S.M., 2011. Do remittances promote financial development?. Journal of development economics, 96(2), pp.255-264.

2. Ali, M. and Puah, C.H., 2018. Does bank size and funding risk effect banks' stability? A lesson from Pakistan. Global Business Review, 19(5), pp.1166-1186.

3. Anginer, D., Demirgüç-Kunt, A. and Zhu, M., 2013. How does bank competition affect systemic stability?. Journal of Financial Intermediation, Forthcoming. 
4. Arpa, M., Giulini, I., Ittner, A. and Pauer, F., 2001. The influence of macroeconomic developments on Austrian banks: implications for banking supervision. Bis Papers, 1, pp.91-116.

5. Berger, A.N. and Humphrey, D.B., 1997. Efficiency of financial institutions: International survey and directions for future research. European journal of operational research, 98(2), pp.175-212.

6. Berger, A.N. and Mester, L.J., 1997. Inside the black box: What explains differences in the efficiencies of financial institutions?. Journal of banking \& finance, 21(7), pp.895947.

7. Berger, A.N., Klapper, L.F. and Turk-Ariss, R., 2017. Bank competition and financial stability. In Handbook of competition in banking and finance. Edward Elgar Publishing.

8. Brunnermeier, M., Crockett, A., Goodhart, C.A., Persaud, A. and Shin, H.S., 2009. The fundamental principles of financial regulation (Vol. 11). Geneva: ICMB, Internat. Center for Monetary and Banking Studies.

9. Borio, C. and Lowe, P., 2002. Assessing the risk of banking crises. BIS Quarterly Review, 7(1), pp.43-54.

10. Claessens, S. and Forbes, K., 2001. International financial contagion: An overview of the issues and the book. International financial contagion, pp.3-17.

11. Čihák, M., Demirgüč-Kunt, A., Feyen, E. and Levine, R., 2013. Financial development in 205 economies, 1960 to 2010 (No. w18946). National Bureau of Economic Research.

12. Demirgüç-Kunt, A. and Detragiache, E., 1998. The determinants of banking crises in developing and developed countries. Staff Papers, 45(1), pp.81-109.

13. Drehmann, M. and Tarashev, N.A., 2011. Systemic importance: some simple indicators. BIS Quarterly Review, March.

14. Indraratna, Y., 2013. Strengthening financial stability indicators in the midst of rapid financial innovation: updates and assessments. Research Studies.

15. Jahn, N. and Kick, T., 2012. Determinants of banking system stability: A macro-prudential analysis. Finance Center Münster, University of Münster.

16. Kaminsky, G.L. and Reinhart, C.M., 1999. The twin crises: the causes of banking and balance-of-payments problems. American economic review, 89(3), pp.473-500.

17. Khemraj, T. and Pasha, S., 2009. The determinants of non-performing loans: an econometric case study of Guyana.

18. Langrin, B., 2002. An Early Warning System for the Prevention of Banking Sector Crises in Jamaica. Bank of Jamaica Working Paper.

19. Orozco, M., 2006. International Flows of Remittances: Cost, competition and financial access in Latin America and the Caribbean-toward an industry scorecard. Washington, DC: Inter-American Dialogue.

20. Salas, V. and Saurina, J., 2002. Credit risk in two institutional regimes: Spanish commercial and savings banks. Journal of Financial Services Research, 22(3), pp.203224.

21. Sundararajan, V., Enoch, C., San Jose, A., Hilbers, P., Krueger, R., Moretti, M. and Slack, G., 2002. Financial soundness indicators: analytical aspects and country practices (Vol. 212). Washington, DC: International Monetary Fund.

22. Trpeski, L., 2004. Macroeconomic stability and structural banking reforms in the Republic of Macedonia, NBRM.

23. Van den End, J.W., 2006. Indicator and boundaries of financial stability (No. 097). Netherlands Central Bank, Research Department.

24. Zhang, J., Jiang, C., Qu, B. and Wang, P., 2013. Market concentration, risk-taking, and bank performance: Evidence from emerging economies. International Review of Financial Analysis, 30, pp.149-157. 


\section{APPENDIX}

\section{Multiple linear regression model}

\begin{tabular}{|l|c|c|c|}
\hline \multicolumn{1}{|c|}{ Variables Entered/Removed $^{\mathrm{a}}$} \\
\hline 1 & \multicolumn{1}{|c|}{ Variables Entered $_{\text {Model }}$} & $\begin{array}{c}\text { Variables } \\
\text { Removed }\end{array}$ & \multicolumn{1}{|c|}{ Method } \\
\hline 1 & $\begin{array}{l}\text { ROE, BANK DEPOSITS TO GDP, INTEREST RATES FOR } \\
\text { DEPOSITS, BANK CONCENTRATION }\end{array}$ & & Enter \\
\hline
\end{tabular}

a. Dependent Variable: NPLS

b. All requested variables entered.

\begin{tabular}{|l|r|r|r|r|}
\hline \multicolumn{5}{|c|}{ Model Summary } \\
\hline 1 & $\mathrm{R}$ & $\mathrm{R}$ Square & Adjusted R Square & Std. Error of the Estimate \\
\hline a. Predictors: (Constant), ROE, BANK DEPOSITS TO GDP, INTEREST RATES FOR DEPOSITS, BANK CONCENTRATION
\end{tabular}

a. Predictors: (Constant), ROE, BANK DEPOSITS TO GDP, INTEREST RATES FOR DEPOSITS, BANK CONCENTRATION

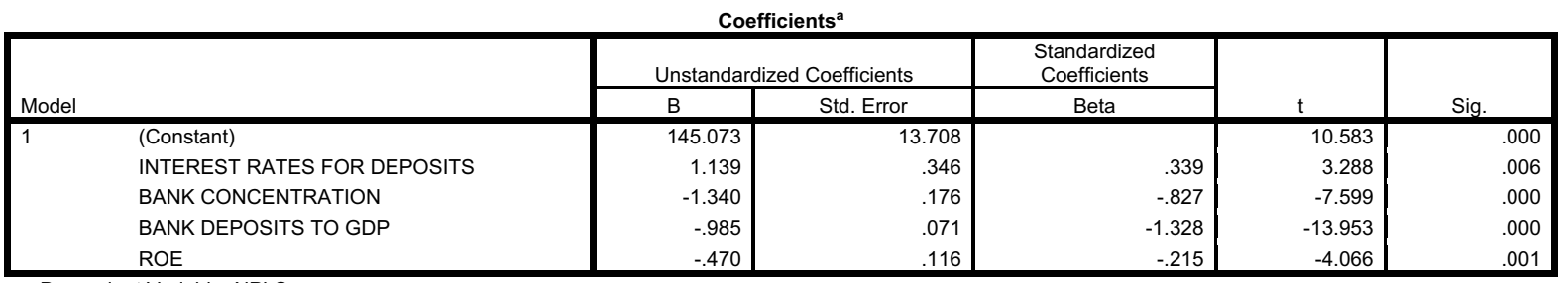

a. Dependent Variable: NPLS
\begin{tabular}{|l|l|c|c|}
\hline \multicolumn{1}{|c|}{ Variables Entered/Removed $^{\mathrm{a}}$} & Variables Removed & Method $^{|c|}$ \\
\hline 1 & Model & & Enter \\
\hline
\end{tabular}

a. Dependent Variable: CAPITAL ADEQUACY

b. All requested variables entered.

\begin{tabular}{|c|c|c|c|c|}
\hline Model & $\mathrm{R}$ & R Square & Adjusted R Square & $\begin{array}{l}\text { Std. Error of the } \\
\text { Estimate }\end{array}$ \\
\hline 1 & $.951^{\mathrm{a}}$ & .905 & .889 & 1.5989566 \\
\hline
\end{tabular}

a. Predictors: (Constant), Lerner index, BANK DEPOSITS TO GDP $\quad$ Coefficients $^{\text {a }}$

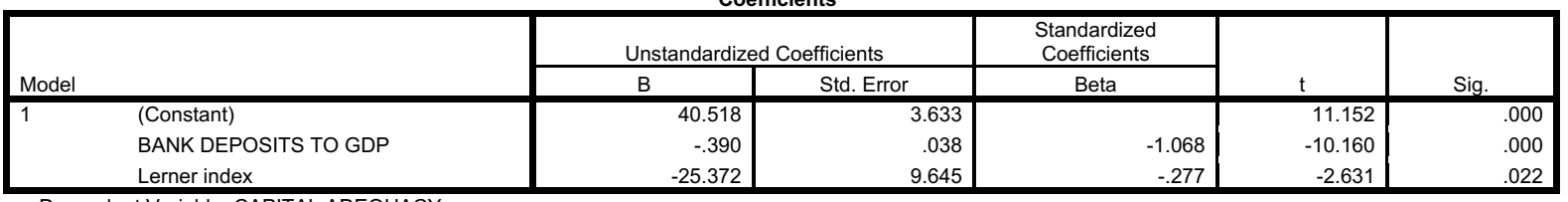

a. Dependent Variable: CAPITAL ADEQUACY 